\title{
STUDI EKSPLORASI NILAI NILAI BUDAYA DALAM KONSEP RELATIONSHIP MARKETING
}

\author{
Ekawati Rahayu Ningsih ${ }^{1}$, Wahyudin Darmalaksana ${ }^{2}$ \\ ${ }_{1}^{1}$ Institut Agama Islam Negeri Kudus, Kudus \\ ${ }^{2}$ Universitas Islam Negeri Sunan Gunung Jati, Cirebon \\ $\bowtie$ ekawatirahayun@yahoo.co.id; yudi_darma@uinsgd.ac.id
}

\begin{abstract}
Tujuan penulisan ini adalah untuk mengeksplorasi teori terkait dengan hubungan antara nilai-nilai budaya konsumen dengan potensi membangun pemasaran hubungan. Penelitian tentang hal ini penting karena pada saat ini para pelaku bisnis harus menyadari bahwa membangun hubungan bisnis jangka panjang sangat penting untuk mendapatkan keuntungan seumur hidup. Selanjutnya, pelaku bisnis juga harus mengetahui bahwa nilai-nilai budaya hidup di masyarakat, melekat pada perilaku individu dan mempengaruhi keputusan untuk tetap berhubungan atau tidak berhubungan dengan relasi bisnisnya. Penelitian ini berbasis pada kajian berbagai teori dan hasil temuan penelitian yang terkait dengan nilai-nilai budaya dan pola-pola membangun pemasaran hubungan. Hasil dari kajian ini menunjukkan bahwa nilai-nilai budaya yang hidup di masyarakat berpotensi membangun pemasaran hubungan. Penelitian ini banyak kekurangan, diantaranya adalah hanya menggunakan data sekunder dan artikel hasil kajian teori. Tentunya hal ini menjadi keterbatasan penelitian ini yang bisa di tindaklanjuti oleh peneliti berikutnya untuk menguji secara empiris hasil temuan.
\end{abstract}

Keywords $\quad$ : Cultural Value, Relationship Marketing Concept.

\section{LATAR BELAKANG}

Pada saat ini telah terjadi pergeseran paradigma tujuan bisnis pada para pelaku bisnis. Awalnya tujuan bisnis diarahkan hanya sekedar untuk mendapatkan keuntungan semata. Tetapi pada saat ini tujuan bisnis secara luas diarahkan untuk menciptakan dan mempertahankan hubungan yang saling menguntungkan baik diantara para pelaku bisnis maupun dengan pelanggan yang dipilih. Pergeseran paradigma ini menyebabkan semakin banyak perusahaan yang berfokus untuk membangun dan mempertahankan hubungan bisnis jangka panjang sehingga bisa menghasilkan profitabilitas dan pertumbuhan bisnis yang lebih tinggi.

Untuk mendukung hal diatas, maka perusahaan harus memfokuskan kegiatan pemasarannya pada upaya membangun hubungan jangka panjang dengan pelanggan daripada hanya menciptakan produk. Karena tujuan pemasaran adalah mengembangkan hubungan yang dalam dan bertahan lama dengan orang dan organisasi yang dapat secara langsung maupun tidak langsung mempengaruhi kesuksesan aktifitas pemasaran perusahaan (Kotler, 2009: 21). Masing-masing 
strategi dan kegiatan harus dievaluasi secara terus menerus sehingga diketahui capaian kinerjanya (Claycomb dan Martin, 2002).

Salah satu konsep penting untuk membangun hubungan jangka panjang dengan pelanggan adalah konsep pemasaran hubungan (relationship marketing/RM). Tujuan relationship marketing adalah membangun hubungan jangka panjang yang saling memuaskan dengan konstituen kunci guna mendapatkan dan mempertahankan bisnis. Empat konstituen kunci untuk pemasaran hubungan adalah pelanggan, pegawai, mitra pemasaran (saluran, pemasok, distributor, dealer, agent), dan anggota masyarakat finansial (pemegang saham, investor, analis). Pemasar harus menghormati kebutuhan untuk menciptakan kemakmuran diantara semua konstituen ini dan mengembangkan kebijakan serta strategi untuk menyeimbangkan pengembalian bagi semua pemegang kepentingan kunci. Untuk mengembangkan hubungan yang kuat dengan konstituenkonstituen ini di butuhkan pemahaman tentang kemampuan dan sumber daya mereka, juga kebutuhan dan keinginan mereka (Kotler, 2009: 22).

Sebagian besar pendapat mengatakan bahwa relationship marketing (RM) adalah filosofi atau budaya yang harus menembus seluruh organisasi. Ini merupakan kombinasi dari proses bisnis dan teknologi yang digunakan untuk memahami pelanggan tentang siapa mereka, apa yang mereka lakukan, apa yang mereka sukai dan mengubahnya menjadi pelanggan setia yang selalu kembali membeli produk-produk perusahaan. Strategi ini merupakan pendekatan yang sangat sistematis untuk mengelola hubungan yang saling menguntungkan antara perusahaan dengan pelanggannya.

Zeithaml and Bitner (2003) menyatakan bahwa tujuan utama dari pemasaran hubungan bisa untuk membangun dan mempertahankan pelanggan yang komit saja dan menguntungkan bagi perusahaan, dan pada waktu yang sama mampu meminimumkan waktu dan usaha yang dikeluarkan untuk pelanggan yang kurang menguntungkan. Sedangkan Kotler (2009:23) menekankan pemasaran hubungan pada kegiatan mempertahankan pelanggan lama maupun baru karena menarik pelanggan baru membutuhkan biaya lima kali lebih besar dari pada mempertahankannya.

Beberapa studi empiris terkait dengan pengembangan relationship marketing (RM) dilakukan oleh Malthouse dan Blattberg, 2005; Donkers et al, 2007; Hwang et al, 2004) yang berhasil mengembangkan model untuk mengukur dan memprediksi nilai sumur hidup pelanggan (Customer Lifetime Value/CLV) untuk berbagai segmen pelanggan. Ryals dan Knox, 2005; Helgesen, 2006; Haenlein et al, 2007 dan Ho et al, 2006, meneliti peran dan dampak dari berbagai prediktor yang digunakan untuk mengukur CLV.

Sedangkan menurut Jain dan Singh (2002), tidak ada cara baku untuk mengukur keberhasilan relationship marketing. Mereka menyatakan bahwa belum tentu satu model bisa berlaku untuk semua kategori produk. Hal ini di dukung oleh Haenlein et al. (2007), yang menyatakan bahwa secara substansial masing-masing industri dan negara memiliki karakteristik yang berbeda sehingga pengukuran relationship marketing juga berbeda. 
Adanya kesenjangan (gap) teori dan pengukuran diantara para ahli tentang relationship marketing sebagaimana disebutkan di atas menjadi keterbatasan yang menjadi peluang bagi penulis untuk mengkaji lebih mendalam tentang teori dan konsep relationship marketing.

\section{TEORI DAN METODE}

\subsection{Relationship Marketing Concept}

Menurut Peterson (1995), munculnya pemikiran ke arah pemasaran hubungan adalah suatu upaya terintegrasi untuk mengidentifikasi, mempertahankan dan membangun jaringan kerja dengan individu konsumen. Jaringan tersebut terus diperkuat agar memberikan manfaat bagi kedua belah pihak melalui kontak interaktif, bersifat individual dan memberikan nilai tambah untuk jangka panjang.

Lahirnya pemasaran hubungan menunjukkan adanya suatu perubahan penting dalam sistem nilai dan orientasi filosofis. Hal ini ditandai dengan teori pemasaran baru yang menyatakan bahwa kepuasan pelanggan masih dipandang perlu, namun tidak lagi cukup sebagai satu-satunya tujuan pemasaran. Tujuan dari pengembangan pemasaran hubungan dilakukan berdasarkan satu struktur manfaat jangka panjang dan ikatan antara pembeli dan penjual. Variabel yang menandainya adalah network relationship yang meliputi kepercayaan (trust), komitmen dan norma sosial.

Berry (1983) pakar pemasaran yang pertama kali memperkenalkan istilah dan definisi pemasaran hubungan memberikan definisi sebagai berikut:"Relationship Marketing is attracting, maintaining and in multi-service organization- enhancing customer relationships the attraction of new customer is merely the first step in the marketing process, cementing the relationship, transforming indifferent customer into loyal oness, serving customer as client-this is marketing too." Definisi tersebut menekankan bahwa pemasaran hubungan merupakan tahap lanjutan untuk meraih pelanggan baru, yaitu dengan membina hubungan dengan pelanggan agar tetap loyal pada perusahaan. Berdasarkan ini, Berry dan Parasuraman (1991) menyatakan bahwa "relationship marketing concerns attracting, developing, and retaining customer relationships."

Lebih lanjut menurut Gummesson (1999: 236) hubungan relasional yang dibangun pada organisasi jasa adalah sebagai hubungan, jaringan kerja dan interaksi. Dari perspektif praktisi, dipertimbangkan sebagai strategi untuk meningkatkan hubungan yang ada dan meluaskan kedalaman hubungan (dengan cara menginvestasikan uang lebih banyak pada produk dan jasa perusahaan) dan dengan mengkonsentrasikan bisnis pada pelanggan yang paling menguntungkan. Ini adalah marketing-oriented management, tidak terbatas pada departemen pemasaran atau penjualan saja tetapi menjadi bagian dari total manajemen perusahaan.

Hennig Thurau dan Hansen (2000) menyatakan bahwa konsep pemasaran dibangun berdasarkan empat hal yang berbeda tetapi saling berhubungan yaitu: pendekatan teoritikal pendekatan perilaku, pendekatan jaringan kerja dan pendekatan institusi ekonomi baru. pendekatan perilaku meliputi model yang berhubungan 
dengan pemasaran hubungan seperti konstruk kepercayaan, komitmen, kepuasan dan customer retention. Sebaliknya, teori jaringan kerja memusatkan perhatian pada karakter interaktif dari relationship dalam bidang business to business marketing dan berhubungan dengan perspektif hubungan antar organisasi.

Dalam model jaringan kerja (network model), perusahaan terlibat dalam sejumlah pengelolaan jangka panjang yang kompleks yang disebut dengan hubungan jaringan kerja (network of relationship). Sementara, new institutional economics approach mencoba untuk menggunakan teori ekonomi modern untuk menjelaskan perkembangan dan hambatan hubungan yang meliputi teori biaya transaksi (transaction cost theory) dan teori agen (agency theory) yang bertujuan meminimumkan biaya strukturisasi dan mengelola hubungan.

Parvatiyar dan Sheth (1994) memandang "pemasaran hubungan sebagai suatu orientasi yang mengembangkan interaksi yang erat dengan pelanggan terpilih, pemasok dan pesaing untuk menciptakan nilai melalui usaha kerjasama. Beberapa pandangan yang lain mengenai pemasaran relasional seperti yang disampaikan oleh Bicket (1992) menyatakan bahwa "pemasaran relasional adalah pemasaran database yang menekankan pada aspek pemasaran yang dihubungkan dengan usaha-usaha database."

Berdasarkan literatur pemasaran jasa yang ada pada waktu itu, Grönroos (1991) mengidentifikasi dan memasukkan adanya profitable outcomes bagi penjual dan pembeli dengan mengusulkan bahwa: "relationship marketing act to establish, maintain, and enhance relationship with customers and other parties at a profit so that the objectives of the parties involved are met. This is done by mutual echange and fulfillment of promises."

Interaksi merupakan konsep utama dalam pemasaran jasa serta memberikan kontribusi pada pemasaran hubungan. Banyak literatur pemasaran jasa yang berusaha memusatkan perhatian pada service encounter yaitu interaksi antara pelanggan dengan penyedia jasa. Pada faktanya, teori pemasaran dan produksi harus bekerja sama dalam teori inti pemasaran jasa untuk menghasilkan produk/jasa yang berkualitas. Konsep tentang service encounter dan service quality mendukung usaha manajemen kualitas modern dan menjembatani kesenjangan antara pemasaran dan fungsi tehnis. Pemasaran jasa adalah induk dari pemasaran internal yang hasilnya dapat diaplikasikan secara umum. Secara keseluruhan perusahaan jasa membutuhkan transmisi dan pemrosesan data dalam hubungan elektronik (the electronic relationship), dan hal ini sangat penting.

Chan (2003) menyatakan bahwa tujuan utama pemasaran hubungan sebenarnya adalah untuk menemukan Life Time Value (LTV) dari pelanggan. Setelah Life Time Value (LTV) didapat, tujuan selanjutnya adalah bagaimana agar Life Time Value (LTV) masing-masing kelompok pelanggan dapat terus diperbesar dari tahun ke tahun. Setelah itu, tujuan ketiga adalah bagaimana menggunakan profit yang didapat dari dua tujuan pertama tadi untuk mendapatkan pelanggan baru dengan biaya murah.

Dengan demikian tujuan jangka panjangnya adalah menghasilkan keuntungan terus menerus dari dua kelompok pelanggan yaitu pelanggan sekarang dan pelanggan 
baru. Zeithaml and Bitner (2003) menyatakan bahwa tujuan utama dari pemasaran hubungan adalah untuk membangun dan mempertahankan pelanggan yang komit yang menguntungkan bagi perusahaan dan pada waktu yang sama bisa meminimumkan waktu dan usaha yang dikeluarkan untuk pelanggan yang kurang menguntungkan.

Model Economic, Resource and Social Contents of Relationship yang disampaikan Morgan (2000:483) menunjukkan adanya pengaruh social content terhadap kepercayaan dan komitmen, pengaruh resource content terhadap komitmen, pengaruh kepercayaan terhadap komitmen dan kerjasama, dan pengaruh komitmen terhadap kerjasama. Model Morgan tersebut dikembangkan dengan menggabungkan beberapa teori dan penelitian terdahulu. Model yang dikembangkan tersebut seperti terlihat pada pengaruh economic content terhadap kepercayaan (trust) yang dikembangkan dari teori Doney dan Cannon (1997) dan Lin et al. (2003). Doney dan Cannon (1997) menyatakan bahwa nasabah dimotivasi untuk percaya pada pemberi jasa yang menawarkan economic content sebagai pihak yang dapat dipercaya karena kesediaan memberikan penawaran ini diartikan sebagai kapabilitas dari pemberi jasa. Kapabilitas ini dapat menimbulkan kepercayaan nasabah, yang berarti penilaian terhadap kemampuan bank untuk memenuhi kewajibannya.

Teori Doney dan Cannon ini diperkuat oleh penelitian Lin et al. (2003) yang menemukan bahwa economic content berpengaruh positif dan signifikan terhadap kepercayaan. Pengaruh economic content terhadap kepuasan dikembangkan dari temuan Liang dan Wang (2005) yang menemukan bahwa economic content secara signifikan mempengaruhi kepuasan nasabah. Nasabah merasa puas karena menurut penilaiannya bank dapat memberikan manfaat ekonomi yang melebihi harapannya. Bank yang dapat memberikan economic content kepada nasabah dengan memberikan manfaat yang lebih besar dari pada pengorbanan yang dikeluarkan akan menimbulkan kepuasan kepada nasabah.

Pengaruh resource content terhadap kepercayaan dikembangkan dari penelitian yang dilakukan oleh Lacey (2003) yang menemukan bahwa resource content berpengaruh signifikan terhadap kepercayaan. Perusahaan yang memiliki resource content akan membuat pelanggan mempercayai perusahaan dan bersedia untuk mengembangkan relationship. Resource content berpengaruh terhadap kepercayaan karena resource content mengurangi ketidakpastian, meningkatnya rasa aman pelanggan, dan menguatnya persepsi pelanggan terhadap reputasi perusahaan. Pengaruh resource content terhadap kepuasan dikembangkan oleh Gwinner et al. (1988) yang menemukan bahwa resource content berpengaruh signifikan terhadap kepuasan. Resource content dirasakan sebagai bagian dari kinerja jasa dan manfaat yang diterima pelanggan dapat mempengaruhi kepuasan pelanggan terhadap jasa. Karena itu resource content dianggap bernilai dan penting bagi pelanggan.

Pengaruh kepuasan terhadap komitmen dikembangkan dari studi Boonajsevee (2005), dan Hennig-Thurau et al. (2002). Hasil penelitian mereka menunjukkan bahwa peningkatan kepuasan pelanggan akan membangun komitmen yang lebih kuat terhadap suatu bank. Jadi nasabah akan puas apabila bank dapat memenuhi atau 
melebihi harapan mereka dan kurang suka mengembangkan hubungan yang baru dengan bank lain apabila sudah memiliki kedekatan emosional yang kuat dengan suatu bank tertentu.

Pengaruh komitmen terhadap relationship intention dikembangkan dari penelitian Moorman et al. (1993) yang menyatakan bahwa pelanggan yang komit dengan relationship dapat memiliki kecenderungan yang lebih besar untuk ingin tetap menjalin hubungan dengan perusahaan karena kebutuhan mereka untuk tinggal konsisten dengan komitmen mereka. Komitmen pelanggan adalah bukti dari adanya emosi yang menstranformasikan perilaku pembelian berulang menjadi suatu relationship. Jika nasabah tidak merasakan adanya kedekatan dengan suatu bank, maka hubungan antara nasabah dan karyawan bank tidak memiliki karakteristik suatu hubungan.

Temuan Mormaan et al. (1993) ini didukung oleh studi yang dilakukan Venetis dan Ghauri (2004). Venetis dan Ghauri menggunakan komitmen sebagai variabel antara yang memainkan peran penting dalam membentuk hubungan jangka panjang. Penemuan dalam penelitian ini menunjukkan bahwa komitmen berpengaruh signifikan pada relationship intention. Dengan kata lain relationship intention dibentuk dari adanya komitmen dari pihak-pihak yang terlibat dalam relationship intention.

\subsection{Strategi Relationship Marketing Dalam Membentuk Kepuasan Hubungan}

Menurut prinsip-prinsip pemasaran hubungan, bisnis yang sukses harus mampu meningkatkan hubungan kepuasan klien. Dengan demikian akan meningkatkan kinerja perusahaan. Di masa lalu, kepuasan hubungan telah dikonseptualisasikan sebagai prasyarat untuk kualitas hubungan. Crosby dan Stevens (1987) mengidentifikasi tiga tingkat hubungan kepuasan yaitu: interaksi dengan personil, inti layanan, dan organisasi. Dalam studi mereka terhadap nasabah asuransi, Crosby dan Stevens (1987) menemukan bahwa ketiga tingkat kontribusi untuk kepuasan secara keseluruhan berada dalam ranah hubungan. Dalam konteks bisnis, kepuasan hubungan telah didefinisikan sebagai keadaan afektif positif yang dihasilkan dari perusahaan yang menilai semua aspek hubungan kerja dengan perusahaan lain (Anderson dan Narus, 1990; Ganesan, 1994; Dwyer et al, 1987).

Secara empiris, tingkat kepuasan berpengaruh pada suksesnya pemasaran hubungan, tetapi tidak secara otomatis mengarahkan konsumen untuk melakukan pembelian ulang (Reichheld dan Aspinall, 1993). Beberapa studi telah meneliti hubungan antara kualitas pelayanan dan kepuasan konsumen, dan mereka menyoroti terdapat peran anteseden kepuasan konsumen dalam persepsi kualitas layanan (Bolton dan Drew, 1991; Boulding et al, 1993). Temuan yang benar-benar paling mendukung hubungan sebab-akibat (Anderson et al, 1994.; Cronin dan Taylor, 1992; Dick dan Basu, 1994) dan penelitian ini sejalan dengan De Wulf et al (2001).

Studi Smith dan Barclay (1997) mengkonsep hubungan kepuasan afektif dari wilayah negara dengan budaya yang berbeda dan hasilnya lebih rasional. Penelitian ini mengemukakan bahwa hubungan kepuasan sebagai variable akumulatif 
mempengaruhi proses hubungan dan bukan sebagai hasil dari transaksi tertentu (Anderson et al, 1997). Selain itu, dalam upaya untuk menghindari tumpang tindih antara persepsi terhadap kualitas layanan dan persepsi hubungan, penelitian ini mengkaji hubungan kepuasan sebagai penilaian hubungan secara keseluruhan (global).

Hennig-Thurau et al (2002), menggunakan tiga variabel inti (kepuasan, kepercayaan, dan komitmen) sebagai kepuasan hubungan, sehingga ketiganya dianggap berpengaruh positif terhadap loyalitas sebagai hasil hubungan. Hubungan kepuasan dilihat pada saat menilai secara keseluruhan hubungan dengan perusahaan pemasok; trust dilihat sebagai tingkat kepercayaan klien dalam integritas pemasok, dan komitmen dianggap sebagai keinginan abadi membeli perusahaan dan melanjutkan hubungannya dengan vendor. Setiap variable dieksplorasi secara lebih rinci.

Pentingnya hubungan kepuasan dan kepercayaan sebagai indikator tatanan konstruk kualitas hubungan yang lebih tinggi, telah dibahas oleh berbagai penulis (Crosby et al, 1990; Dwyer et al, 1987; Shamdasani dan Balakrishnan, 2000; HennigThurau et al, 2001). Hal ini diperkuat oleh Woo dan Ennew (2004) yang menyatakan bahwa hubungan kualitas disebut sebagai konstruksi tingkat tinggi dalam berkerjasama dan beradaptasi dalam suatu atmosfer kualitas hubungan secara keseluruhan. Mereka memberikan bukti adanya pengaruh langsung dan positif dari kualitas hubungan pada kualitas pelayanan tetapi gagal untuk membangun hubungan yang sama dengan kepuasan dan niat perilaku.

\subsection{Nilai Nilai Budaya}

Pengertian budaya menurut Hofstede (1984) adalah cara berpikir dari kelompok manusia yang membedakan anggota dari suatu kelompok terhadap kelompok yang lain, yang berinteraktif secara keseluruhan dari ciri-ciri umum yang mempengaruhi respon dari kelompok manusia terhadap lingkungannya. Hofstede (1983) telah meneliti empat dimensi budaya yaitu penghindaran ketidakpastian, power distance, maskulinity-feminity, individualisme-collectivisme dalam mempelajari perusahaan multinasional. Penjelasan pola-pola budaya menurut Hofstede (1984) yaitu:

1. Penghindaran Ketidakpastian

Penghindaran ketidakpastian adalah pola budaya masyarakat yang mencoba menghindari ketidakpastian. Di suatu wilayah yang anggota masyarakatnya sedikit akan memiliki pola penghindaran ketidakpastian lebih rendah dibandingkan dengan wilayah yang jumlah anggota masyarakatnya banyak. Dalam budaya yang penghindaran ketidakpastiannya tinggi, perilaku agresif dapat diterima meskipun individu harus menahan agresi dengan cara menghindari konflik dan kompetisi. Orang yang berada pada budaya yang penghindaran ketidakpastiannya tinggi mencoba menhindari ambigouity dan mengembangkan aturan dan ritual dalam setiap situasi yang memungkinkan. Pola penghindaran ketidakpastian ini berguna dalam memahami perbedaan apabila 
berkomunikasi dengan orang asing. Sedangkan pada budaya penghindaran kepastian tinggi, biasanya terdapat keinginan kuat untuk mencapai konsensus bersama.

\section{Power distance}

Pola budaya power distance menunjukkan seberapa besar kesiapan anggota dari institusi dan organisasi menerima kekuatan yang diberikan secara tidak seimbang. Individu dari budaya power distance yang tinggi akan menerima kekuatan sebagai bagian dari masyarakat. Hasilnya, power distance yang superior, akan mempertimbangkan subordinatnya secara berbeda dari mereka dan sebaliknya. Anggota dari budaya yang power distance-nya tinggi, akan melihat kekuatan sebagai kenyataan dasar bagi masyarakat dan menekankan pada pemaksaan atau kekuatan sebagai rujukan utama. Sedangkan pada budaya yang power distance-nya rendah, mereka percaya bahwa kekuatan hanya bisa digunakan untuk melegitimasi keadaan.

Dimensi power distance memfokuskan pada hubungan antara orang yang berada pada status yang berbeda. (antara superiror dan subordinate). Power distance ini berguna dalam memahami perilaku individu ketika berinteraksi dengan orang asing. Rendah dan tingginya power distance tergantung pada karakteristik budaya dimasing-masing nergara. Contoh budaya yang power distance-nya tinggi adalah Mesir, Ethiopia, Ghana, Guatemala, India, Malaysia, Nigeria, Panama, Arab Saudi, dan Veneuzela. Contoh budaya yang power distancenya rendah adalah Australia, Canada, Denmark, Germany, Ireland, Israel, New zeland, Sweden dan Usa.

\section{Maskulinity-feminity}

Pola budaya maskulin cenderung melibatkan penempatan nilai yang tinggi pada suatu kekuatan. Pada budaya maskulinitas, ketegasan mengenai kualitas hidup sangat rendah dibandingkan dengan budaya feminin. Sistem budaya yang mempunyai index masculinity tinggi cenderung menekankan pada perbedaan peran sosial, performance, ambisius dan independen. Sedangkan sistem budaya yang mempunyai index masculinity rendah akan menekankan pada peran sex, kualitas hidup, jasa dan interdependence. Hofstede (1983) menyatakan bahwa perbandingan antara orang-orang dalam budaya femininity dan orang-orang dalam budaya maskulin adalah lebih kuat dalam motivasinya untuk mencapai cita-cita dan terpusat pada kerja sebagai pusat kehidupannya.

\section{Individualisme-collectivisme}

Indeks Individualisme (IND) dapat dikontraskan dengan pengertian yang berlawanan dengan budaya kolektivisme. Budaya kolektivisme adalah budaya dimana individu-individunya terorganisir dalam kelompok masyarakat. Tingkat kesetiaan individu dalam kelompok bervariasi dimasing-masing negara. Secara khusus, hal ini bisa mengukur dimensi pentingnya individu dibandingkan dengan pentingnya kelompok. Dalam masyarakat yang tingkat individualistisnya tinggi, maka fokus pemenuhan hak dan kebutuhan individunya juga tinggi. Sedangkan dalam masyarakat kolektivis, kebutuhan kelompok adalah hal yang terpenting. 
Seseorang yang memiliki nilai IND sangat tinggi maka perasaan individualisme juga lebih besar. Seseorang yang memiliki nilai IND lebih rendah maka perasaan individualisme juga sangat rendah.

Terkait dengan budaya cina (confucian work dynamism), ada sekelompok peneliti yang dikomandoni oleh Michael Bond (1987) menguji kesimpulan Hofstede (1983) dengan menggunakan obyek penelitiannya di cina. Mereka menemukan empat dimensi dari variabel budaya yaitu confusian work dynamism, integrasi, human heartness, dan disiplin moral. Tiga dari dimensi ini berhubungan dengan dimensi yang diteliti Hofstede (1983) yaitu hubungan integrasi dengan individualism, disiplin moral dengan power distance dan human heartedness dengan maskulinity dan feminity. Hanya satu dimensi yang tidak berhubungan dengan penelitian hofstede (1983) yaitu confusian work dynamism.

Dimensi ini melibatkan delapan nilai yaitu empat nilai diasosiasikan positif yaitu meliputi: berhubungan, berhemat, tekun dan memiliki rasa malu. Sedangkan empat nilai yang lain diasosiasikan negatif yaitu: perlindungan, personal, respek terhadap tradisi dan pengulangan kembali. Selanjutnya Hofstede (1983) mengemukakan ada empat dimensi kunci yaitu:

1. Stabilitas masyarakat didasarkan pada hubungan tidak sama antar individu

2. Keluarga adalah prototype bagi organisasi sosial

3. Perilaku yang konsisten

4. Berisi edukasi dan kerja kera

Nilai-nilai budaya menurut Mc Carty \& Hattwick (1992) dibagi menjadi enam dimensi pada jenis budaya yang berbeda yaitu :

1. Individual versus kolektif. Ada budaya yang mementingkan nilai-nilai individual dibandingkan nilai-nilai masyarakat, dan ada juga budaya yang mementingkan nilai-nilai kelompok daripada nilai-nilai individual.

2. Maskulinitas/feminitas. Melihat bagaimana peran pria melebihi peran wanita, atau bagaimana pria dan wanita membagi peran.

3. Orientasi waktu. Melihat bagaimana anggota masyarakat bersikap dan berperilaku dengan orientasi masa lalu, sekarang atau masa depan.

4. Menghindari ketidakpastian. Budaya suatu masyarakat berusaha menghadapi ketidakpastian dan membangun kepercayaan yang bisa menolong mereka menghadapi hal itu. Misalnya mereka meyakini dan menghayati agama.

5. Orientasi aktivitas. Masyarakat yang berorientasi pada tindakan dan pada pemikiran.

6. Hubungan dengan alam. Bagaimana suatu masyarakat memperlakukan alam, apakah sebagai pendominasi alam atau justru menjalin harmoni dengan alam.

Dalam suatu masyarakat tertentu, orientasi nilai di atas akan mengalami perubahan sesuai dengan proses adaptasi yang terjadi. Nilai-nilai yang dianut oleh suatu masyarakat dari waktu ke waktu akan terus berubah. Budaya dipelajari, dimiliki dan disosialisasikan dari satu generasi ke generasi. Budaya bercirikan konservatif, menolak dan sulit untuk berubah dan menginginkan kelanjutan. 
Wallendorf \& Reilly dalam Mowen (1995) memberikan definisi budaya adalah seperangkat pola perilaku yang secara sosial dialirkan secara simbolis melalui bahasa dan cara-cara lain pada anggota dari masyarakat tertentu. Trompenaars (1994), seorang peneliti budaya dalam studi organisasi, mengatakan bahwa "it is my belief that you can never understand other cultures. Sementara itu Hofstede (1984) melakukan "cross-cultural studies" dengan meneliti para karyawan IBM pada 40 negara sebagai partisipan dalam meneliti "international differences in work-related values".

\section{HASIL DAN PEMBAHASAN}

\subsection{Hubungan Antara Nilai-nilai Budaya Dengan Potensi Membangun Relationship Marketing Untuk Tujuan Bisnis Jangka Panjang}

Terkait dengan pengembangan relationship marketing, akibat berlakunya konsep globalisasi terhadap dunia internasional saat ini membawa berbagai konsekuensi yang sangat luas dalam setiap aspek kehidupan manusia tanpa terkecuali, termasuk dalam bidang bisnis dengan seluruh komponen yang mendukung bidang bisnis tersebut. Para manajer dalam rangka mengelola organisasi perusahaannya memerlukan visi dan perspektif global, jika mereka ingin mencapai sukses. Batasan negara dan budaya sudah tidak mampu menghambat atau membatasi organisasi dari tekanan persaingan luar, sehingga kesuksesan organisasi sangat ditentukan oleh kemampuan manajer atau pimpinan untuk beradaptasi dalam lingkungan internasional yang bukan saja jauh lebih luas tetapi juga sangat dinamis dan penuh dengan berbagai peluang dan tantangan.

Sehubungan dengan hal tersebut diatas berbagai persiapan telah dilakukan oleh mayoritas perusahaan yang memiliki jangkauan operasi di berbagai negara atau lebih dikenal dengan Multi Nasional Corporation (MNC), mulai dari meningkatkan daya saing produk yang mereka hasilkan, memberikan berbagai pengetahuan tentang lingkungan internasional, mengamati strategi bersaing yang dilakukan oleh para pesaing mereka sampai kepada perubahan kebijakan yang dilakukan terhadap penilaian prestasi atau kinerja bagi seorang calon manajer yang akan dipromosikan untuk menjalani penugasan luar negeri terlebih dahulu (expatriates), agar mereka mampu dan memiliki pengalaman yang lebih luas dengan nuansa yang sangat berbeda dari situasi dan kondisi lingkungan domestik pekerjaan yang selama ini mereka tekuni. Keberhasilan mereka mengemban penugasan tersebut menjadi penilaian prestasi mereka untuk jabatan yang lebih tinggi (Avery, Baradwaj, Singer, 2008).

Penugasan internasional menjadi semakin penting saat ini dan telah menjadi bagian dari karir para manajer. Sebagai konsekuensi dari kondisi tersebut maka kompetensi kepemimpinan lintas budaya sangat diperlukan dalam perusahaan yang beroperasi secara internasional. Secara lebih nyata kondisi ini akan sangat mempengaruhi interaksi antara manajer yang ditugaskan ke luar negeri (expatriates manager) dengan para karyawan lokal mereka, karena sangat diperlukan adanya adaptasi baik oleh manajernya maupun oleh karyawannya. 
Bagi para manajer hal tersebut sangat erat hubungannya dengan gaya kepemimpinan yang harus diterapkan akibat dari perbedaan budaya yang mereka miliki. Bagi karyawan lokal, mereka juga harus menerima serta menyesuaikan perilaku terhadap perubahan gaya kepemimpinan yang diterapkan manajer yang mempunyai pandangan global. Karena keberhasilan dalam penyesuaian kedua belah pihak merupakan kunci sukses bagi kinerja organisasi secara keseluruhan. Oleh karena itu interaksi antar budaya harus semakin intens agar terjadi difusi dan penetrasi nilai-nilai budaya sehingga terjadi adaptasi yang cukup tinggi.

Kebanyakan pengetahuan tentang masalah-masalah dalam kepemimpinan silang budaya berawal dari situasi di mana manajer-manajer internasional yang ditugaskan ke Amerika. Graen dan Wakabayashi (1994) meneliti perusahaan-perusahaan yang memiliki pabrik di Amerika dan Jepang, seperti cabang Toyota yang berlokasi di Amerika serikat tetapi diorganisasikan dengan menggunakan metode atau cara Jepang dengan sebagian besar karyawannya adalah orang Amerika. Hal ini akan bisa dilaksanakan dengan baik dan sukses apabila para karyawan dan managernya memiliki kemampuan dan kepemimpinan lintas budaya.

Sementara pada faktanya, kemampuan dan kepemimpinan tersebut menghadapi masalah yang sangat rumit akibat dari adanya perbedaan budaya antar kedua negara. Beberapa masalah yang muncul, antara lain:

- Perbedaan bahasa yang menyebabkan komunikasi dan kerjasama yang rumit di berbagai tingkatan manajerial.

- Para manajer dan pekerja Jepang menganggap bahwa manajer-manajer Amerika memiliki kepatuhan yang rendah terhadap perusahaan dan dalam partner kerja.

- Para manajer Amerika menjumpai kesulitan dengan ketiadaan dari hukuman bagi pelanggaran terhadap perintah yang dianggap ideal.

- Para manajer Amerika melihat kurangnya kemegahan dari kantor perusahaan sebagai symbol status yang hilang, seperti: kantor pribadi, lokasi parkir tersendiri, ruang pertemuan bagi manajemen dan sebagainya.

- Para manajer Amerika tidak menjalani seluruh karirnya pada satu perusahaan saja, sebaliknya para manajer Jepang berharap untuk dapat bekerja sampai pensiun pada satu perusahaan saja.

Meskipun diantara berbagai negara telah dilakukan penyesuaian budaya dengan baik terhadap manajemen partisipatif, namun demikian organisasi secara menyeluruh harus menyesuaikan bentuk dari partisipasi tersebut terhadap budaya lokal atau budaya setempat. Oleh karenanya saat ini bagi para manajer global harus dapat secara fleksibel mengubah pendekatan mereka jika mereka diberi penugasan di luar negeri dan bekerja dengan orang-orang yang berasal dari berbagai budaya asing yang berbeda.

Sehubungan dengan kondisi tersebut, saat ini bagi perusahaan-perusahaan yang bergerak secara internasional memerlukan orang-orang yang memiliki "cross-cultural competence" dan "cultural sensitivity", dengan cara menerapkan berbagai persyaratan tambahan dalam rekrutmen calon-calon karyawan mereka. Dengan begitu diharapkan para karyawan akan memiliki daya adaptasi yang tinggi dan memiliki kemampuan 
kepemimpinan silang budaya yang handal (Ratiu dalam Weinshall, 1993). Adapun berbagai persyaratan tambahan tersebut antara lain meliputi: mampu beradaptasi, fleksibel, memiliki sifat keterbukaan yang tinggi (open minded), memiliki banyak teman atau relasi dari berbagai kewarganegaraan yang berbeda, menguasai berbagai bahasa yang secara internasional sering dipergunakan dalam operasi bisnis internasional.

Karena setiap kelompok masyarakat tertentu akan mempunyai cara pandang yang berbeda dalam menjalani kehidupannya dengan sekelompok masyarakat yang lainnya. Definisi di atas menunjukkan bahwa budaya merupakan cara menjalani hidup dari suatu masyarakat yang ditransmisikan pada anggota masyarakatnya dari generasi ke generasi berikutnya. Proses transmisi dari generasi ke generasi tersebut dalam perjalanannya mengalami berbagai proses distorsi dan penetrasi budaya lain. Hal ini dimungkinkan karena informasi dan mobilitas anggota suatu masyarakat dengan anggota masyarakat yang lainnya mengalir tanpa hambatan.

Agar budaya terus berkembang, proses adaptasi seperti dijelaskan di atas perlu dilakukan. Paradigma yang berkembang adalah bahwa budaya itu dinamis dan dapat merupakan hasil proses belajar, sehingga budaya suatu masyarakat tidak hadir dengan sendirinya. Proses belajar dan mempelajari budaya sendiri dalam suatu masyarakat disebut enkulturasi (enculturati). Enkulturasi menyebabkan budaya masyarakat tertentu akan bergerak dinamis mengikuti perkembangan zaman. Sebaliknya sebuah masyarakat yang cenderung sulit menerima hal-hal baru dalam masyarakat dan cenderung mempertahankan budaya lama yang sudah tidak relevan lagi disebut sebagai akulturasi (acculturation).

Budaya yang ada dalam sekelompok masyarakat merupakan seperangkat aturan dan cara-cara hidup. Dengan adanya aturan dan cara hidup anggota dituntun untuk menjalani kehidupan yang serasi. Masyarakat diperkenalkan dengan adanya baikburuk, benar-salah dan adanya harapan-harapan hidup. Dengan aturan seperti itu orang akan mempunyai pijakan bersikap dan bertindak. Jika tindakan yang dilakukan memenuhi aturan yang telah digariskan, maka akan timbul perasaan puas (satisfaction) dalam dirinya dalam menjalani pekerjaan dan kehidupan. Rasa bahagia juga akan dirasakan oleh anggota masyarakat jika dia mampu memenuhi persyaratanpersyaratan sosialnya. Orang akan sangat bahagia jika mampu bertindak baik menurut aturan budayanya. Oleh karena itu, budaya merupakan sarana untuk memuaskan kebutuhan anggota masyarakatnya.

Pada budaya Indonesia, yang secara notabene masuk dalam kategori budaya Asia Tenggara memiliki karekteristik yang multicultural dan unik. Di Indonesia hidup enam jenis agama dan masing-masing pemeluknya bisa hidup berdampingan satu dengan yang lain. Masyarakat Indonesia juga memiliki banyak kategori budaya dan sub budaya yang saling mendapatkan pengakuan antara satu dengan lainnya. Karena keragaman dan keunikannya inilah maka perusahaan asing yang hidup di Indonesia harus bisa beradaptasi dengan kondisi unik Indonesia, lingkungan sosial dan budayanya.

Jika dihubungkan dengan empat dimensi budaya dari Hofstede (1984), maka Indonesia memiliki karakteristik budaya yang hampir sama dengan negara-negara 
Asia Tenggara lainnya seperti Cina, Malaysia, Filiphina, Jepang dll yaitu: power distance-nya tinggi, menganut faham maskulinity, collectivisme, dan penghindaran ketidakpastiannya tinggi. Sedangkan secara umum karakteristik konsumennya adalah sebagai berikut: cenderung berfikir jangka pendek, berfikir tidak terencana, suka berkumpul, gagap teknologi, berorientasi pada konteks, menyukai merk luar negeri, religious, gengsinya tinggi, dan kuat dalam memegang subculture.

Oleh karena hal diatas, Bahee (1992), Henderson dan Venkatraman (1999), Venkatraman (1989), Venkatraman dan Camillus (1984) mengembangkan tentang konsep kecocokan budaya (cultural fit) yang menggabungkan antara teori kecocokan (fit) dan teori budaya nasional dan kemudian diterapkan pada penelitian tentang bagaimana masyarakat melakukan adopsi teknologi informasi. Konsep "cocok" atau "kesesuaian" ini ada di beberapa literatur tentang manajemen strategi.

Kecocokan (fit) berakar dari konsep 'cocok' atau 'menyelaraskan' sumber daya organisasi dengan peluang dan ancaman lingkungan. Hal ini merupakan usaha untuk menemukan cara terbaik membentuk strategi bisnis berkesinambungan dengan mempertimbangkan berbagai komponen organisasi, yang harus cocok antara satu dengan yang lain untuk menghasilkan kinerja yang optimal (Donaldson 2001; Drazin dan Van de Ven, 1985; Ginsberg dan Venkatraman, 1985; Venkatraman, 1989). Dengan demikian, untuk mencapai kinerja yang optimal sebagaimana pada adopsi teknologi B2B di Thailand, sangat penting bagi perusahaan untuk mengadopsi teknologi yang cocok dalam konteks budaya Thailand.

Kecocokan budaya juga bisa digunakan untuk menyelidiki bagaimana teknologi ditransfer dari negara-negara Barat sehingga bisa sesuai dengan kondisi negara penerimanya. Hewett et al. (2006) menyatakan bahwa kebudayaan nasional merupakan faktor penting dalam hubungan yang dijalin dalam hubungan B2B. Karena gagasan teknologi B2B dan kecocokan budaya, maka penelitian ini hanya berfokus pada pengaruh budaya nasional Thailand pada komunikasi dan hubungan bisnis ke bisnis di Negara Thailand. Selanjutnya, Savanik, John, dan Prem (2010), dalam hasil studi empirisnya menunjukkan bahwa penggunaan (utilisasi) teknologi yang dikembangkan dari aspek kualitas pelayanan teknis (B2B), dimoderasi oleh faktorfaktor kecocokan budaya pengguna/pelanggan (cultural-fit).

\section{PENUTUP}

Hasil dari eksplorasi teori terkait dengan hubungan antara nilai-nilai budaya konsumen dengan potensi membangun pemasaran hubungan, hasilnya adalah bahwa sejak diperkenalkannya konsep atau teori pemasaran hubungan oleh Berry (1983), dan diperkuat dengan fakta bisnis global yang menuntut adanya pertukaran nilai-nilai budaya antar negara, maka penelitian tentang hal ini sangat dibutuhkan baik di ranah teori maupun kajian empiris. Jika dihubungkan dengan empat dimensi budaya dari Hofstede (1984), maka Indonesia memiliki karakteristik budaya yang hampir sama dengan negara-negara Asia Tenggara lainnya seperti Cina, Malaysia, Filiphina, Jepang dll yaitu: power distance-nya tinggi, menganut faham maskulinity, collectivisme, dan 
penghindaran ketidakpastiannya tinggi. Sedangkan secara umum karakteristik konsumennya adalah cenderung berfikir jangka pendek, berfikir tidak terencana, suka berkumpul, gagap teknologi, berorientasi pada konteks, menyukai merk luar negeri, religious, gengsinya tinggi, dan kuat dalam memegang subculture.

Berbekal dari nilai-nilai budaya inilah, menjadi pertimbangan bagi perusahaanperusahaan multi nasional ketika akan membangun bisnis dan pemasaran hubungan untuk tujuan bisnis jangka panjang harus memperhatikan nilai-nilai budaya yang berkembang di masyarakat tempat bisnis itu berdiri.

Peneliti menyadari bahwa penulisan ilmiah yang merupakan hasil penelitian ini masih banyak kekurangan, diantaranya adalah hanya menggunakan data-data sekunder berupa buku-buku literatur dan jurnal ilmiah terkait dengan tema. Maka rekomendasi bagi peneliti berikutnya adalah menguji secara empiris validitas eksplorasi hasil temuan pada obyek sehingga konsep nilai-nilai budaya dalam pemasaran hubungan bisa berkembang. Selain itu waktu yang dibutuhkan dalam penelitian ini sangat terbatas sehingga dibutuhkan longitudinal study untuk menambah wawasan peneliti dan hasil temuan.

\section{DAFTAR PUSTAKA}

Baudrillard, Jean P. (2004) Masyarakat Konsumsi. Yogyakarta : Kreasi Wacana.

Berry, J.W. (1979) A cultural ecology of social behavior. In L Berkowitz ( Ed), Advances in Experimental Social Psychology, 12, pp. NY: Academic Press.

Berry, J.W., Kim, U. and Boski, P. (1988) Psycological Acuulturation of Immigrants, in Kim, Y.Y. and Gudykunst, W.B. (Eds), Cross-cultural Adaptation: Current Approaches, Sage Publications, Newbury Park, CA

Bitner, M. (2001) Service and technology: opportunities and paradoxes, Managing Service Quality, Vol. 11 No. 6.

Hewett, K, Money, RB \& Sharma, S. (2006) National culture and industrial buyers-seller relationships in the United States and Latin America, Journal of Academy of Marketing Science, vol. 34, no. 3, pp. 386-402.

Hofstede, G. (1980) Culture's consequences: International differences in work related values, Sage, Beverly Hills, CA.

Hofstede, G. (1984) Culture's Consequences: International Differences in Woek-relate Values, Sage Publication, Beverly Hills.

Hofstede, G. (1991) Cultures and organisations: Software of the mind, McGraw-Hill, USA.

Hofstede, G. (2001) Culture's Consequences: Comparing Values, Behaviours, Institutions and Organisations Across Nations, 2nd edn, SAGE, USA.

Kotler dan Keller (2009), Manajemen Pemasaran, Erlangga, Edisi 13

Parasuraman, A., Zeitham, V.A. and Berry, L.L. (1985) A Conceptual model of service quality and its implication for future research. Journal of Marketing; Vol. 49 No.4.

Zeithaml, V.A., Berry, L1. and Parasuraman, A. (1996) The behavioural consequences of service quality, Journal of Marketing, Vol. 60, pp. 31-46.

Vatanasakdakul, S \& D'Ambra, J 2007, A conceptual model for e-commerce adoption in developing countries: a task-technology fit perspective, International Journal of Information Technology and Management, no. Special Issue on Making Sense of the 'e'phenomenon: The Essence of E-Commerce, E-Business, E-Government and ELearning., vol 6 